\title{
AN ANALYSIS OF STUDENT'S RECOUNT TEXT IN SYSTEMIC FUNCTIONAL LINGUISTIC PERSPECTIVES
}

\author{
Ni Kadek Heny Sayukti, Eri Kurniawan \\ Universitas Pendidikan Indonesia \\ kadekheny@student.upi.edu, erikurn@gmail.com
}

Received: 22-03-2018

Revised: $28-03-2018$

Accepted: 28-03-2018

\begin{abstract}
As a demand of English learning, eighth grade students need to be able to write a recount text about their personal experiences. For this reason, this study employs a qualitative case study research design to analyse students' writing of recount text. The data were obtained by collecting students' writing in two different classes of eight grade junior high school in Bandung, Indonesia during the even semester of academic year 2016/2017. The self-composed recount texts were selected based on different proficiency levels as suggested by the English teacher of the school. For the framework of the text analysis, this study draws on Systemic Functional Linguistic theory, and recount text. Meanwhile, content analysis was employed to explore the analysis of the writing. The results presented that majority of problems on the students' writings consist of social function and language feature. In terms of language features, there were still several errors in spelling, punctuation and capitalization. In term of Interpersonal metafunction, errors usually occurred in the Finite as there was an overlap of past tense and present tense. As a result, it was found that most of the clauses were written in material process and it still lack of reference in the theme-rheme structure.
\end{abstract}

Keywords: recount text, systemic functional linguistic, writing

\section{INTRODUCTION}

Indonesian population is multilingual with various regional languages across the archipelago. There are about 700 languages of which more than 150 are spoken by over 10,000 speakers in Indonesia (Hamied, 2015, p. 32). For English as a foreign language, there is a scrutiny in the teaching process to face the intervention challenge. Regarding to the influence of English to Indonesian language, an approximate percentage of $57 \%$ are drawn from English words, meanwhile others are borrowed from Arabic (18\%), Javanese (18\%), Dutch $(2.5 \%)$, and Jakarta Dialect (1.2\%) (Wijana, 2009 in Wijana, 2014). To learn English as a foreign language, there may be no doubt that Indonesian student might experience difficulty in terms of structure and context. In other words, this condition is also considered as interlanguage which describes the language learner develops a linguistic system of his native language (L1) in mastering the target language (L2) (Selinker, 1972). In brief, it is a condition when L1 influences the L2 linguistic system and causes an error in representing a proper target language. Therefore, it is significant to address this issue in order to provide educational resources for teaching in teaching writing.

Regarding the current curriculum in Indonesia, there have been several studies of Systemic Functional Linguistics (SFL) perspectives on students' writing analysis in EFL setting. Nurohmah (2013) studied writings of eighth semester students of English Department in one university in Bandung, Indonesia. Using SFL analysis, majority of students cannot differentiate between the use of simple present, past tense, irregular, regular verb, and prepositional phrase (Nurohmah, 2013). In another case study conducted in junior high school in Indramayu, Indonesia, most of the students still made mistakes in identifying past verb in writing recount text (Yulianawati, 2015).
Noviyanti (2015) reveals that mostly students used the reiteration pattern by repeating the same element as a theme and employed the zigzag pattern to make a sense of cumulative development of a text. Another study identified that transliteration is also the most common interference used by the students, followed by omission errors, spelling errors, incorrect pronoun use and incorrect word use (Owu-Ewie \& Lomotey, 2016). Meanwhile, this study concerns on the analysis of student's error in recount text writing. Taken in one junior high school in Bandung, Indonesia, the analysis of the writings is viewed in the aspect of lexico-grammar analysis using mood structure, transitivity structure and theme structure as parts of interpersonal metafunction, experiential metafunction and textual metafunction. Therefore, based on the preliminary research in the research site, interlanguage found in the students' writing and extended to major mistakes related to metafunctions.

The syllabus of English subject aims at developing the competency to communicate in both spoken and written language through integrating the four language skills, listening, speaking, reading and writing. Previously, the English curriculum was underpinned by systemic functional linguistics (SFL) and genre-based approach (GBA) to support the relationship between language and its function in social settings. However, since Curriculum 2013 is implemented, it turns to scientific approach with the support of communicative competence; therefore the demand to the teacher's creativity may rise. Unfortunately, many teachers do not have much knowledge about teaching genres in the classroom (Derewianka, 2003). Based on the research by Derewianka (2003), teachers seem to emphasize the generic structure of genres which often leads to the confusion. Moreover, the teaching process tends to focus only on limited subtypes of genres. For instance, the teacher is only teaching a personal 
recount while neglecting other type of recount like historical recount and factual recount. Therefore, it might affect students' understanding in composing the target text.

As previous studies mostly concern on the analysis of recount text based on the grammatical error, this study intends to analyse students' selfcomposed recount text in SFL perspectives and its implication toward the meaning of the text. Therefore, a critical analysis is carried out in the context of SFL perspectives; hence it gives a comprehensive reflection of the actual teaching result and the learning objective. Besides, analysing student's writing through SFL perspectives could help teachers understand how the students create contextual meaning in their composition through its structure and organization. As a result, this paper attempts to explore the incorporation of lexicogrammar analysis (mood, theme and transitivity) into students' recount writing. The results are expected to contribute upon the development of teaching writing through SFL perspectives for future teachers' lesson plan. Furthermore, the information in this study can be alternative sources and guidance for future researches on the same interest.

\section{A. The Nature of Teaching Text in 2013 Curriculum}

Concerning with Ministerial Regulation No. 23 The year 2015 about National Literacy Movement, the recent curriculum aims at fostering student's interest in reading as a demand for $21^{\text {st }}$ Century teaching and learning (Buku Saku Gerakan Literasi, 2016). Previously, the English curriculum was underpinned by SFL and Genre-based Approach (GBA) in which language skills are taught based on the productive skills and receptive skills. In general, the implementation of GBA in the previous curriculum was also to enhance students' communicative competence. The competence refers to the definition proposed by Canale (1983), including grammatical competence, sociolinguistic competence, discourse competence and strategic competence. The four major elements highlight the importance of integrating communicative competence into language teaching approach. The types of genre developed in curriculum cannot be applied without the development of other competences (Zhuang, 2007). At the moment, the focus of language teaching were seen clear but the practice of language teaching in Indonesia could not be adjusted in a quick process.

Several problems also occurred in implementing genre based approach in the national curriculum (Triastuti, 2011). The method used in Indonesia is different from the context of Australia where the genre based approach was initially implemented to develop students' literacy skills in writing and reading in the context of English as a first and second language whereas in Indonesia, it is used to teach integrated language skills (Hakim et al., 2016). In Indonesia, mostly teachers tend to misinterpret the standards of content into appropriate input texts. Teachers need to measure to what extent their selected text must be complex and authentic. Authentic texts are supposed to be produced in the course of genuine communication, not specially for purposes of language teaching (Nunan, 1999, p. 79) and that is teacher's creativity that plays a role to fit it into the classroom environment. Once again, the core problem is our situation when teachers are still not sufficiency enough to design a course independently. Therefore, the adoption of the genrebased approach has yet to bring satisfactory outcomes in terms of students' mastery of English language in Indonesia.

\section{B. The Nature of Recount Text}

Retelling past event is happening in daily life. In the form of a recount text, the students must retell the sequence of events or experiences which they have ever got in the past (Nafisah \& Kurniawan, 2007 , p. 65). Basically, there are three types of recount: personal recount, factual recount, and imaginative recount. Recount text consists of orientation, record of events, and reorientation (Anderson \& Anderson, 2003, p. 50). It is marked by time and developed through series of events arranged in a chronological order. The writer/ speaker can also add any personal comment in the form of exposition, interpretation or evaluation to emphasize the incidents happened in the events. Language feature is very significant since the success of retelling event lie in the choice of word used by the writer or speaker. Based on Derewianka (1990), types of recount go along with their language features. For instance, specific participants such as Mrs. Fiona, Mr. Morgan and so forth are used as a reference of personal closeness toward the text. The other features are including specific participants, circumstance of time and place, first person, additive conjunction, material process, and past tense (Gerot and Wignell, 1994, p. 194). Students also need to acquire imaginative recount which involves an imaginary role and giving details of events. It means that students do not only retell but social process of a recount constitute to how students learn to narrate, to explain and to describe by activating their fund knowledge (Knapp \& Watkins, 2005). Based on the overview, it can be concluded that the teaching of recount text is an act of helping students in retelling personal experiences, histories or past events in a chronological order with meaningful choice of word.

\section{Interpersonal, Experiential and Textual} Metafunctions in Recount Texts

This section attempts to analyse whether a recount text is coherent and meaningful based on its schematic structure, social function and linguistic feature. Meanwhile, interpersonal metafunctions, textual metafunction and experiential metafunction will elaborate the work of students' in more specific explanation.

\section{Recount Text in Interpersonal Metafunction}

In communicative exchange, there are four basic speech roles proposed by Halliday, giving 


\section{RETORIKA: Jurnal Ilmu Bahasa , Vol. 4, No. 1 April 2018, Page 55}

information, demanding information, giving good-\& -services and demanding good-\&-services (Thompson, 2014). Since the purpose of recount is retelling past event, giving information is a fundamental purpose of communicative exchange in this case. It is usually written in declarative form. Interpersonal metafunction is realized by the Mood structure in which consist of Mood, Finite and Residue. There are also other parts such as the combination of predicator (verbal group) and complement (nominal group) and (optionally) adjuncts: comment adjunct, mood adjunct, and conjunctive adjunct. The Finite or lexical verb is fused due to the situation of past event. The lexical verb is usually written/spoken in the form of past tense (verb II) such as went, came, ate, sang, and etc. Modality might appear in several parts, meanwhile, Residue is formed from the emergence of adjuncts (adverbial group, and or prepositional phrase). Since recount deals with sequencing event, there are several types of adjunct, such as conjunctive Adjuncts include items such as for instance, anyway, moreover, meanwhile, therefore, nevertheless (Gerot \& Wignell, 1994). There might be several comment Adjuncts include such items as frankly, apparently, hopefully, broadly speaking, understandably, to my surprise.

\section{Recount in Experiential Metafunction}

The experiential metafunction deals with the clause as a representation through transitivity structure (Gerot \& Wignell, 1994) with three main important parts, circumstance, participant and processes. It is used to express feeling, things, and thought including participant in certain circumstance. Since recount is mainly talking about events, it deals with action and reaction. There are five major processes used in recount text. First, it deals with material process because physical action is embedded to text, such as entered, throw, went, saw and etc. Therefore, the participant has the role as an actor of the process. Other element can take position as circumstance and as goal as the thing affected by the process. Recount text also concerns with mental process as it records people's engagement with their cognition, and senses. In fact, this process is a process of cognition such as thinking and knowing, process of perception such as seeing and observing, and process of feeling/affect such as wanting and liking. The participant is considered as Senser as doer of the process and other participants as a nominal group or clause conveying what is felt, thought or perceived.

Very often, we find verbal process in a recount text because the speaker/writer tend to cite, quote or directly say something. These are realised by two distinct clauses: the projecting clause encodes a signal source (Sayer) and a signalling (Verbal Process) and the other (projected clauses) realises what was said (Gerot \& Wignell, 1994). As recount tends to be declarative, relational process is also found in its form. It refers to the process which establish an identity are called Identifying processes and processes which assign a quality are called
Attributive processes. The participants are called carier, token or value. In the sense of transitivity structure, there is also a possibility of ergativity appears in the recount text. For example, the word grow. It could be used in the sentences "I grew some flowers. It grew in my back yard." In the first sentence, the verb requires direct object which can be considered as a transitive form and the second one it turns into intransitive. For more elaboration, it could be found in practice and analysed by using material process.

\section{Recount text in Textual Metafunction}

The concept of textual metafunction uses the structure of theme and rheme. The term theme itself is used to refer a formal category of a starting point of utterance or as Halliday calls it a 'point of departure'. Basically, theme does not always refer to the subject of a sentence but the left-most important constituent of the sentence. Furthermore, theme is identified in declarative clause and non-declarative clause in which elaborating why subject is not always the theme of every clause. The order of how information is received usually goes by the theme, thematisation and stage. Conjunction also plays an important role as it functions to show logical relationship between particular clauses in the text. The sentence will be error if the conjunction 'because' is not there. It essentially aims to show logical relationship of result and reason between these two clauses. Basically, conjunctive Adjuncts such as however, therefore, alternatively, as a result show how the clause fits to the whole unit. Since the recount deals with sequence, text presents the conjunctive adjuncts play role to keep the story coherent. The examples of conjunctive adjuncts in maintaining the ordered events are the use of then, after that, next and so on.

\section{METHODS}

The present study intends to explore how student's recount text writing is analysed through the perspectives of SFL. Concerning to the phenomenon, the researcher utilised a qualitative case study approach. A qualitative case study design is useful to address explanatory questions to a social phenomenon (Hamied, 2017). The fact that case study is closely related to its generalizability, Punch and Oancea (2014) believe that there are some types of case where generalization is not the main purpose of the study. Therefore, the data was collected from two students' works of recount text during English class. The writings were deliberately chosen from two female students at the eighth grade of a junior high school in Bandung, West Java, Indonesia during the even semester of academic year $2016 / 2017$. The two writings were chosen based on the consideration that both of them represent the problems faced in writing class. The content analysis approach was used to analyse writing errors of students in the recount text. The data collected through the process of observing, analysing and interpreting. At first, a semi-structured interview was done with the English teacher. The questions of 
the interview were carried out based on the problems faced by the students in learning recount writing and the teacher in teaching writing. Furthermore, the researcher analysed and diagnosed the metafunctions in the samples to find out its appropriateness with the theories underlying recount text. As a result, a comprehensive analysis was done based on the social function, schematic structures, and language features from SFL perspectives namely interpersonal metafunction, experiential metafunction, and textual metafunction.

\section{FINDINGS AND DISCUSSION}

The section intends to represent how student' recount writing text are analysed in SFL perspectives, especially in terms of interpersonal metafunction, experiential metafunction and textual metafunction.

\section{A. The Genre Analysis and the Social Function of the Text}

The analysis of genre is done through an analysis of generic structure of the student's handwriting text. Ideally, recount text consists of orientation, record of events, and reorientation (Anderson and Anderson, 2003; Derewianka, 1990). Meanwhile, the analysis of generic structure is as follows:

Table 1.

The generic structure of the recount text

\begin{tabular}{cccc}
\hline TEXT & Orientation & Events & Reorientation \\
\hline Text 1 & $\mathrm{P}$ & $\mathrm{P}$ & - \\
\hline Text 2 & $\mathrm{P}$ & $\mathrm{P}$ & $\mathrm{P}$ \\
\hline
\end{tabular}

Based on the table 1, the students' recount writings have completed a structure of recount text. Both of the recount texts are written in the form of personal recount. In terms of social function, personal recount is a text which retells activities in the past (Anderson and Anderson, 2003). In this text, the writer retells her personal experience on her birthday in series of events. The orientation of the text is written in the first paragraph to orient the readers to the in an introduction of setting and characters. There are basically three events in the general organization. Mostly happened at school, in the classroom and at home, meanwhile the setting of time vary from the morning of her birthday (Event 1) until the next day of her birthday (Event 2 and Event 3), specifically during the after school. The first event is about her disappointment over the plain reaction of her birthday. Then, the second event is talking about the next day morning of her birthday. Unfortunately, the reorientation is not included in the text. It is usually written to summarize the experience and sometimes offers personal comments of the writer about the whole sequence of events (Derewianka, 1990). Based on the overview, it can be seen that the ability of the writer is sufficient enough to fulfil the criteria of writing recount text.

\section{B. Language Features Analysis in SFL Perspectives}

The lexico-grammar analysis of the text was identified through the analysis of mood structure, transitivity structure and theme structure as parts of interpersonal metafunction, experiential metafunction and textual metafunction. This session explores how the clauses are structured to deliver the message expressed in each metafunction.

\section{Interpersonal Metafunction Analysis}

The interpersonal metafunction explores how relationship between the semantic organization of interaction and grammatical differences in the Mood structure of clauses (Eggins, 2004). Basically, mood choices can be seen through the form of clauses and sentences. The following figure describes the distribution of sentences and clauses of the student's authentic handwriting recount text.

Table 2.

The distribution of sentences and clauses in the text

\begin{tabular}{lc}
\hline Total of Clauses/Sentences & Total \\
\hline Clauses & 28 \\
\hline Sentences & 18 \\
\hline Declarative sentences & 28 \\
\hline Positive declarative sentence & 25 \\
\hline Negative declarative sentence & 2 \\
\hline Interrogative declarative sentence & 1 \\
\hline
\end{tabular}

The table shows that there are total 28 clauses in 18 sentences in this text with 25 clauses $(89 \%)$ are positive declarative and the rest are negative and interrogative declarative. It indicates that the student considers the readers as the recipient of information or in the potential role of acknowledger (Eggins, 2004). The fact that she writes her recount text using declarative mood is considered relevant with the characteristic of recount text which is to give information to the readers. Since it is retelling the past, majority of the clauses are also written in past tense with verb II as the Finite. However, there are several errors in which she confuses the tense of the Finite.

Figure 1

The error of Finite (Verb II) in the mood structure

\begin{tabular}{|c|c|c|}
\hline My friends & left & me \\
\hline Subject & Finite & Compliment \\
\hline \multicolumn{2}{|c|}{ Mood } & Residue \\
\hline isn't & it & annoying? \\
\hline Finite & Subject & Compliment \\
\hline
\end{tabular}

Based on the figure, there is an inconsistency of Verb in the text. Taken from the same sentence, the clauses above do not show an agreement in terms of tense. The first Finite is using past tense (left) while the second one is using present tense (isn't). This kind of error occurs in six sentences. For 


\section{RETORIKA: Jurnal Ilmu Bahasa , Vol. 4, No. 1 April 2018, Page 57}

instance, Then I take a bath and ate my breakfast. There is a contradictive form of Finite as ate is already in the correct form, $\mathrm{m}$

eanwhile take is supposed to be took as it follows the tense of telling past event.

Besides, Modal Finite to express ability (could) also appears in several clauses. The use of modal finite in a recount text is probably to show her personal opinion toward a special inability and ability. However, there is an irrelevant form of modal finite as described in the following example:

Figure 2.

The error in Modal Finite

\begin{tabular}{cccc}
\hline I & couldn't & said & Anything \\
\hline Subject & Modal Finite & predicator & Compliment \\
\cline { 2 - 3 } Mood & \multicolumn{2}{c}{ Residue } \\
\hline
\end{tabular}

From the examples shown in the figure 2 , we can see that another inconsistency occurs in the form of negative declarative mood. In this case, the way she uses could over can shows her ability in differentiating the form of the modal finite based on the tense. However, an error occur again as the predicator say is replaced by said after the Modal Finite couldn't. Overall, she has described her experiences in good sequences and complete sentences. However, due to the inconsistency of the Finite, the mood choice of the text might be affected.

\section{Experiential Metafunction Analysis}

Experiential Metafunction identifies how reality is presented in the language. In fact, it involves the exploration of experiential meaning in the clause and logical meaning between the clause complexes (Eggins, 2004). Based on the student's text, it can be summarized that majority of her clauses $(46 \%)$ are written in Material process meanwhile the rest are mental process $(21 \%)$, relational process $(21 \%)$ and verbal process $(12 \%)$. The following figure shows an example of material process taken from the text.

Figure 3

The Material process in the text

\begin{tabular}{cccc}
\hline After that, & I & went & Home \\
\hline Cir: time & Actor & Process: material & Cir: place
\end{tabular}

The way she uses material process as the description of her experience shows her understanding toward social function of recount text to retell an action in the past experiences. She also uses mental process to add her personal comments toward the events. Although the error in the form of verb still occurs, the following example shows the reality of her personal feeling:

Figure 4

The error in mental process

\begin{tabular}{cccc}
\hline On that day, & everything & felts & very annoying \\
\hline Cir: time & Senser & $\begin{array}{r}\text { Process: } \\
\text { mental }\end{array}$ & Phenomenon \\
\hline
\end{tabular}

Most of the participant in her sentences is $I$ but in the figure, it shows some variety as she uses everything. There are two errors in the sentence in which the circumstance of time require the preposition on and the verb felt was mistakenly spelled. This is probably because of the overlap of her understanding toward the use of affix $s$ in the present tense structure.

\section{Textual Metafunction Analysis}

After analysing the interpersonal and experiential structure, textual metafunction is derived to identify topic of the clause. Textual metafunction is expressed by Theme and Rheme (Gerot \& Wignell, 1994; Thompson, 2014). From the sample of the text, it was found that majority of the clause are unmarked. However, the following example shows a marked sentence:

\section{Figure 5}

The theme structure of the text

\begin{tabular}{ll}
\hline On the next day, & I woke up with a low spirit. \\
\hline Theme & Rheme
\end{tabular}

There are several clauses written like figure 5 . She might want to give a better transition for her writing organization and emphasis to a part of the clause. The theme On the next day is marked because it is considered as the most important left part in the expression. She might want to give more emphasis to the explanation of time along with her activities. If we identify the topical change, the sequences of the theme might not follow the normal distribution of theme-rheme structure.

Figure 6

The Theme-Rheme structure in the second paragraph of Text 1

\begin{tabular}{lc}
\hline On the next day, & I woke up with a low spirit. \\
\hline Theme 1 & Rheme 1 \\
\hline Then, & I take a bath and ate breakfast. \\
\hline Theme 2 & Rheme 2 \\
\hline after that & I went to school \\
\hline Theme 3 & Rheme 3 \\
\hline that day & everything felts very annoying. \\
\hline Theme 4 & Rheme 4
\end{tabular}

The figure shows that every sentence is marked by the sequence of time. Although, most of the theme is written as the pronoun I, there are marked sentences which put more emphasis on parts of the clause. As a review, most of elaboration of the event lacks of reference. From the first sentence to the second sentence, it almost bring a new topic because there is an absence of the use of pronoun such as it, this, that or those to refer back to the theme or rheme in the previous sentences. However, she has made an effort of giving clear information which still can form coherence. Therefore, both of the recount texts still cover an appropriate schematic structure and organization. 
Figure 7

The Theme-Rheme structure in the first paragraph of Text 2

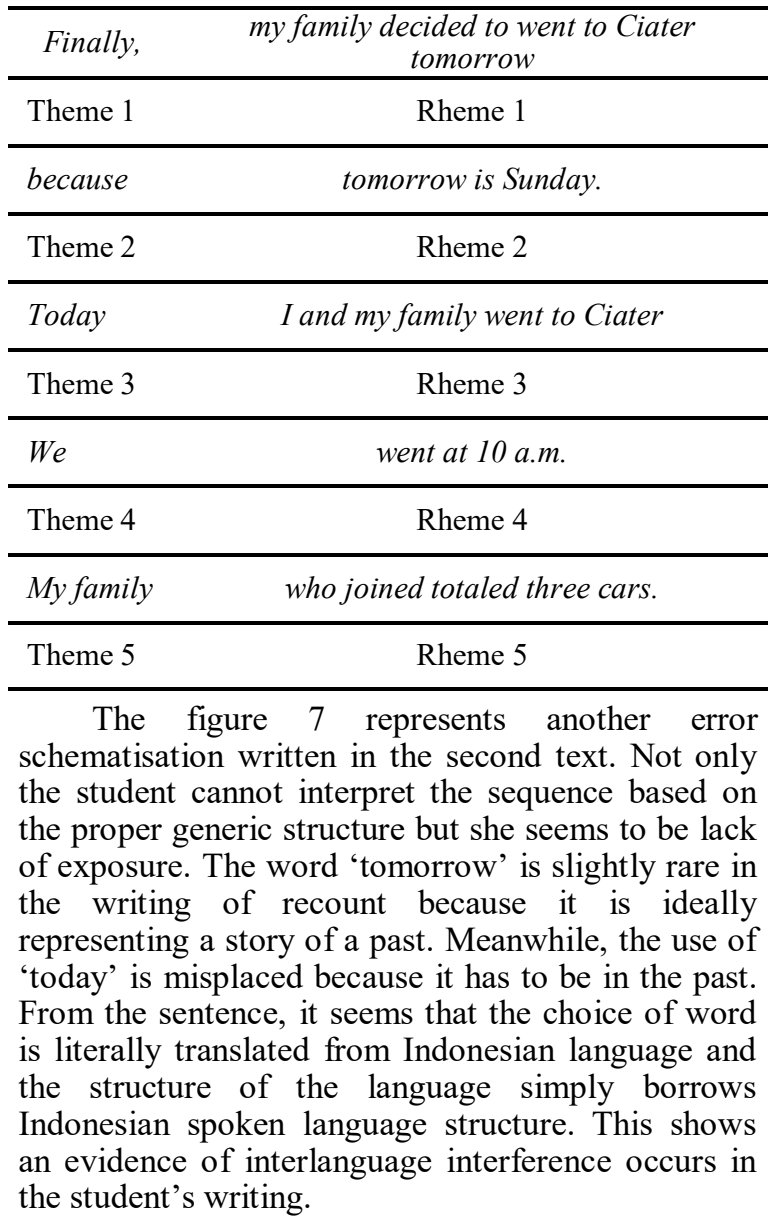

\section{CONCLUSION}

Based on the overview, it is clear that the students have made their best efforts to write a recount text about their experiences. However, they revealed two important findings related to the generic structure and linguistic features of the genre. First, in terms of the generic structure, they have performed a good control in writing recount text. It can be seen from the schematic structure of the recount texts. In terms of language features, there are still several errors in spelling, punctuation and capitalization. In term of Interpersonal metafunction, errors usually occur in the Finite as there is an overlap of past tense and present tense. Basically, mood choices derived in the text is suitable enough to the characteristic of the recount text, which is declarative. Using transitivity structure, it is found that most of the clauses are written in material process and it still lack of reference in the themerheme structure. The roles of teachers are critical in maintaining on-going process of writing. In conclusion, learning writing cannot be done in one sitting. Thus, both teachers and learners have to maintain active communication in order to successfully create a meaningful writing class. Although this study concerns on EFL students and the teaching of writing, the result cannot be generalised to be eligible to all EFL students. Therefore, further researches in larger dimension are required.

\section{ACKNOWLEDGEMENTS}

I would like to express my gratitude to Eri Kurniawan for supervising this project during Functional Grammar course and my very great appreciation to Indonesia Endowment Fund for Education Scholarship for supporting the completion of this project during my postgraduate study.

\section{REFERENCE}

Anderson, M., \& Anderson, K. (2003). Text Types in English 1. Australia: Macmillan.

Canale, M. (1983). From communicative competence to communicative language pedagogy. Language and communication, 1 (1), 1-47.

Cresswell, J. W. (2014). Research Design: Qualitative, Quantitative and Mixed Methods Approaches (4th ed.). SAGE Publications.

Derewianka. (1990). Exploring how texts work. Heinemann Educational Books.

Derewianka, B. (2003). Trends and Issues in GenreBased Approaches. RELC Journal.

Dirgeyasa, I. W. (2016). Genre-Based Approach: What and How to Teach and to Learn Writing. English Language Teaching, 9(9).

Eggins, S. (2004). An Introduction to SystemicFunctional Linguistics. London: Pinter.

Finch, A. E. (2008). The Postmodern Language Teacher: the future of task-based teaching. Retrieved April 07, 2017, from www.finchpark.com/arts/ Postmodern_Language_Teacher.pdf

Fisher, D., \& Frey, N. (2008). Better learning through structured teaching: A framework for the gradual release of responsibility. Alexandria, VA: ASCD.

Gerot, L., \& Wignell, P. (1994). Making Sense of Functional Grammar. Australia: An Introductory Workbook.

Hakim, M., Riswanto, R., \& Rafiska, L. (2016). THE USE OF GENRE-BASED APPROACH IN THE CONTEXT OF ENGLISH FOREIGN LANGUAGE CURRICULUM DEVELOPMENT AT ISLAMIC SCHOOLS IN INDONESIA. PEOPLE: International Journal of Social Sciences, 2(1).

Hamied, F. (2015). ELT Intricacies Within the Indonesian Language Policy. English for ASEAN Integration: Policies and Practices in the Region, 32-40.

Hamied, F. (2017). Research Methods: A Guide for First-Time Researchers. Bandung: UPI Press.

Harmer, J. (2007). The Practice of English Language Teaching. Malaysia: Pearson Education Limited.

Holdich, C. E., \& Chung, P. H. (2003). A ‘computer 
tutor' to assist children develop their narrative writing skills: Conferencing with HARRY. International Journal of HumanComputer Studies, 59(5), 631-669.

Horn, B. (2011). The Future Is Now: Preparing a New Generation of CBI Teachers. English Teaching Forum, 49(3), 2-9.

Indonesian Ministry of Education and Culture. (2016). Buku Saku Gerakan Literasi. Jakarta: Indonesian Ministry of Education and Culture.

Knapp, P., \& Watkins, M. (2005). Genre, text, grammar: Technologies for teaching and assessing writing. UNSW Press.

Nafisah, N., \& Kurniawan, E. (2007). Writing English for General Communication. Bandung: UPI Press.

Noviyanti, N. (2015). THEMATIC PROGRESSION IN STUDENTS'RECOUNT TEXTS. Journal of English and Education, 3(2), 65-76.

Nunan, D. (1999). Second Language Teaching \& Learning. Massachusetts, USA: Heinle \& Heinle Publishers .

Nurlaelawati, I., \& Novianti, N. (2017). The Practice of Genre-Based Pedagogy in Indonesian Schools: A Case of Pre-Service Teachers in Bandung, West Java Province. Indonesian Journal of Applied Linguistics, 7(1), 160-166.

Nurohmah, I. (2013). An Analysis of Students' Recount Text by Using Systemic Functional Grammar. Passage, 89-98.

Ontario Ministry of Education. (2005). A Guide to
Effective Instruction in Writing. Ontario: Queen's Printer.

Owu-Ewie, C., \& Lomotey, C. (2016). L1 (Akan) interference errors in L2 (English) writing: The case of three junior high school students in Ghana. American Journal of Language and Literacy, 1, 1-18.

Sejnost, R. (2010). Building content literacy: Strategies for the adolescent learner. Corwin Press.

Selinker, L. (1972). Interlanguage. IRALInternational Review of Applied Linguistics in Language Teaching, 10(1-4), 209-232.

Thompson, G. (2014). Introducing Functional Grammar Third Edition. New York: Routledge.

Triastuti, A. (2011). Critical Issues in the Implementation of Genre-based Teaching. Retrieved April 17, 2017, from staff.uny.ac.id

Wijana, I. D. (2014). The Use of English in Indonesian Adolescent's Slang. Journal of Language and Literature, 14(1), 8-19.

Yulianawati, I. (2015). AN ANALYSIS OF SYSTEMIC FUNCTIONAL LINGUISTIC OF STUDENTS' RECOUNT TEXTS (A Case Study at a Junior High School in Indramayu). Wacana Didaktika, 3(19), 55-64.

Zhuang, X. (2007). From communicative competence to communicative language teaching. Sino-US English Teaching, 4(9), 39 -45 . 